\title{
A RATIONALIZATION OF TRUST SURCHARGE CASES
}

\section{By James A. Moore $\uparrow$}

With the world depression of the nineteen thirties now behind us and with at least one wing of economic thought issuing dire predictions of an early and equally drastic crash, it is timely to consider a type of litigation which sprouts from economic depression as naturally as weeds from loam-namely, attempts to hold fiduciaries responsible for losses in trust asset values occurring in times of disrupted economic conditions. At this time, when it is possible to review the cases on this topic from an objective point of view and with proper perspective, we can learn lessons from the past which may be important and useful in the future.

In the trust surcharge cases which have arisen after past depressions, the courts have usually taken a very practical approach and nearly always have arrived at what appears to be a sound result. In doing this they have adopted a number of tests against which they have weighed the actions of the fiduciary who is accused of maladministration. The tests adopted are logical enough in themselves, but they have never been woven into a single logical pattern. What the courts have done is to consider any pertinent factors, lump them together, cite a few cases which involve a similar factual set-up, and finally arrive at their own conclusion on the particular case. Although this approach has not resulted in inequity, it has resulted in confusion. The purpose of this article is to attempt to reduce that confusion by analyzing the factors which have had a bearing on the cases, and by submitting an approach that appears to be logical and in accord with the trend of actual judicial decisions. Such an approach would provide a starting point in legal research and, perhaps more important, in the preparation of cases for trial. It might also be of assistance to fiduciaries by making somewhat clearer the minimum the law requires of them in the performance of their duties.

Any attempt at pigeonholing, such as is necessarily involved here, is obviously a risky matter. The law can be oversimplified, and things that are gray can be made to appear black or white. This is particularly true where the courts themselves have not, at least on the sur-

† A. B., 1936, University of Kentucky ; LL. B., 1939, Harvard University ; member of the Philadelphia Bar; author, When Is a Sale Not a Sale, TAXES, THE TAX Magazine, April 1947. 
face, made such an attempt. Yet a careful reading of case after case on this subject leaves the reader with an impression of the whole body of the law that cannot be obtained by study of any one case or group of cases. $^{1}$ The full picture is in the reported cases, but the outlines are blurred and should be brought into proper focus.

Typical of the cases being considered here is one in which a fiduciary receives from a decedent ${ }^{2}$ securities $A, B$, and $C$. He retains $A$, sells $B$ and $C$, and invests the proceeds in $D$. A and D suffer sharp losses, and the beneficiaries complain that the losses were caused by the negligence of the fiduciary.

A case of this type is very similar to an ordinary negligence case, and it is submitted that the fundamental approach used there is equally applicable here. In either case, it must first be determined to what standard of care the defendant (or fiduciary) should be held; next, whether, under the evidence, he has met that standard, and finally, if he has not; whether he can successfully plead an affirmative defense. As is the case with all analogies, this one can be carried too far. Despite the basic similarity, there are many differences between trus't surcharge and torts cases and the torts law terminology used above is perhaps misleading. However, the author believes that the results of the cases justify this terminology.

The answer to each of the three questions posed above must depend upon a consideration of many factors which bear upon that question. This does not mean that a mathematical computation is possible. Some factors, when present, are nearly always important, while others are of use only to tip delicately balanced scales in a close case. Furthermore, the weight of a given factor will vary in different cases depending upon the circumstances. Sometimes one or two factors will be so strong that the others can be largely discounted. Certain combinations of factors nearly always produce the same result. Generally speaking, however, all of the factors which have been given weight by the courts in the past should be considered before a final con-

1. The author has read a large mass of these cases, but does not pretend to have examined all of them. Research has been largely concentrated on Massachusetts, New York and Pennsylvania cases. The greatest body of law on this subject has grown up in these States, and the cases from the other jurisdictions that have been read indicate that the law of these three States is representative: Massachusetts of the "prudent man" rule, New York and Pennsylvania of the "legal list" rule. Surprisingly, it will often be found that a case from another jurisdiction, whether it be prudent man or legal list, will cite decisions of both Massachusetts and New York to support the conclusion reached. See, for example, In re McCann's Will, 212 Minn. 233, 3 N. W. 2d 226 (1942). Actually, this practice is not so illogical as it would at first seem; as will appear later, the theories underlying many of the factors that go into the decision of a trust surcharge case are just the same in both types of State.

2 . For purposes of simplification the word "decedent" is used throughout this article to mean either a testator who has established a testamentary trust or a settlor of an inter vivos trust. With certain minor exceptions, the rules pertaining to each are the same. 
clusion is reached. Naturally, other factors which have not been considered in past cases could become important in future ones, but for obvious reasons this article is limited to those which have assumed at least some importance in the decided cases. These have in turn been classified and each placed under the principal heading on which it bears.

\section{A. Standard of Care}

\section{(1) The "normal" standard}

In arriving at the standard of care by which the fiduciary's conduct is to be tested, it is necessary first to determine what the "normal" standard is. This is a matter of the basic law of trust administration of the state whose law governs the case. When the courts of this country were faced with demands for surcharging fiduciaries, this was the first question they had to decide. Suprisingly (in view of later results) the Massachusetts, New York and Pennsylvania courts came up with about the same answers. ${ }^{3}$ These answers all seemed to be based upon "prudence", or the actions of a "prudent man." It would be natural to suppose, from the similarity of language employed, that the approach to the problem would be the same in all three states. However, there was a wide divergence as to what constituted "prudence." 4 The Massachusetts court became the founder and leading exponent of the "prudent man" rule, a common law conception which declares that equity participations can be proper investments for a prudent man to make. Since the decision in Harvard College v. Amory, ${ }^{5}$ many other states have adopted this rule. Some of these first accepted it as a principle of common law, then made it statutory; in others, a "prudent man" statute changed the previously-existing law. All of the states ${ }^{6}$

3. The rules laid down in the leading cases were:

"All that can be required of a trustee to invest, is, that he shall conduct himself faithfully and exercise sound discretion. He is to observe how men of prudence, discretion and intelligence manage their own affairs, not in regard to speculation, but in regard to the permanent disposition of their funds, considering the probable income, as well as the probable safety of the capital to be invested."

Harvard College v. Amory, 9 Pick. 446, 461 (Mass. 1831).

". . the trustee is bound to employ such diligence and such prudence in the care and management, as in general, prudent men of discretion and intelligence in such matters, employ in their own like affairs."

King v. Talbot, 40 N. Y. 76, 85 (1869).

"Thus, executors and administrators, or trustees, acting with good faith and without any willful default, or fraud, will not be responsible for any loss that may arise. All that a court of equity requires from trustees, is common skill, common prudence, and common caution."

Calhoun's Estate, 6 Watts 185, 188 ( $\mathrm{Pa} .1837$ ).

4. 2 ScotT, TRUSTS, $\$ 227.5$ (1939).

5. See note 3 supra.

6. California, Connecticut, Delaware, Illinois, Kentucky, Maine, Massachusetts, Michigan, Minnesota, Missouri, Nevada, Oregon, Rhode Island, Texas, and Washington. 
which now follow the rule use the language of Harvard College $v$. Amory, either exactly or with only slight variations. ${ }^{7}$

The New York court in King v. Talbot ${ }^{8}$ had a different theory of prudence and adopted, as a matter of common law, the English conception that unsecured investments were per se imprudent, and that the prudent fiduciary should normally restrict himself to a very narrow class of investments. The Pennsylvania court in Calhoun's Estate ${ }^{9}$ was already operating under a "legal list" rule imposed by statute, and its standard of "prudence" was subject to the limitations of that statute.

In the last century the legal list rule was by far the more popular of the two. Some state constitutions have legal list provisions, and many other states (including New York) later enacted similar statutes. Despite the increasing popularity of the prudent man rule today, legal list statutes are still in force in a majority of the States. ${ }^{10}$

It can be seen, then, that from an apparently similar beginning, there soon grew a wide divergence of opinion, drawing the two groups of states farther apart as the theoretical differences became more apparent. All courts still were guided by the test of prudence, but in one instance it was prudence within a very limited field, in the other the scope was much broader.

Some time ago this trend toward markedly different conclusions was reversed, and in more recent years there has been a marked tendency toward similarity of result under the two rules. Lawyers have had a good deal to do with this, as it has become standard practice to put discretionary powers in trust instruments, thus removing the "legal list" restrictions, and the courts seem to have taken up where the lawyers left off. As will be illustrated later in this article, the legal list courts have sometimes gone to rather surprising lengths to avoid

7. In some states, such as Michigan and Minnesota, the standard is that of a prudent man dealing with the property of others.

8. See note 3 supra.

9. Ibid.

10. Most of the statutes are "mandatory"; some are "permissive." Under a mandatory statute the fiduciary, in making investments, is compelled to stay within the list (usually government bonds and first mortgages on realty) and even within the list has the duty of exercising prudence. Under a permissive statute, the fiduciary is protected if he stays within the list and is allowed to go outside the list if he can show he acted with prudence. In practice these distinctions are not so important as would appear. A fiduciary who stays within the limits of a mandatory statute is rarely surcharged; a fiduciary in a "permissive" state who goes outside the list has a very heavy burden of proving prudence.

The following states now have legal list statutes: Alabama, Arizona (permissive), Arkansas, Colorado, District of Columbia, Florida, Georgia, Idaho, Indiana, Iowa, Louisiana, Maryland (permissive), Montana, Nebraska, New Jersey, New Mexico, New York (doubtful whether permissive or mandatory), North Carolina, North Dakota, Ohio (doubtful whether permissive or mandatory), Oklahoma (permissive), Pennsylvania, South Carolina, Tennessee (permissive), Utah (permissive), Virginia (permissive), West Virginia (permissive), Wisconsin, and Wyoming. 
literal application of the statute, and where the statute is not directly involved, the rules governing the conduct of fiduciaries are about the same in all states.

The distinctions between and similarities of the two rules are best discussed under the specific headings of this article. It is sufficient here to point out that, despite the tendency just referred to, it is still most important to determine initially under what rule of law the fiduciary is operating. This rule of law is the starting point of the standard of care: it sets the standard in the first instance, and the other factors discussed here simply raise or lower in the particular case the norm established by the legislature or court of last resort of the state whose law governs the administration of the estate or trust.

\section{(2) Circumstances which vary the "normal" standard}

A step beyond the application of the norm, into a consideration of aberrant factors, is actually in accord with the usual approach, that the final standard is that of a prudent man "under all the circumstances." Certainly no fault can be found with the logic of this, and its accurate application would always result in a proper standard of care being applied. The fault lies not in the logic, but in the vagueness. It is apparent that "all the circumstances" are going to shift the "normal" standard upward or downward. The six factors discussed below are believed to be the most important of these circumstances. Although it is generally said that the standard of care is determined by the will and by the law ("prudent man" or "legal list") governing the conduct of the fiduciary, the cases have shown that the presence of some or all of certain factors favorable to the fiduciary will cause the courts to relax their requirements concerning the evidence of his care and prudence, whereas, if these factors are favorable to the beneficiary, the court will be more strict in judging the fiduciary's conduct. The net result, then, is that these factors bear in such a way upon the standard of care to which a fiduciary will be held that they appear to raise or lower the "normal" standard. ${ }^{11}$

\section{(a) What type of fiduciary is involved?}

On the face of it, there should be a different measure of responsibility applied to executors and trustees. Executors, on one hand, have a duty to convert the assets, pay the debts, and then to turn the distributable remainder over to the beneficiaries. Trustees, on the

11. Another way of putting the same idea would be that the scope of the fiduciary's discretion is broadened or narrowed by these factors. While this seems more accurate when applied to some of the factors (notably the discretionary powers), it is not in the final analysis quite so satisfactory over-all as the standard of care terminology. 
other hand, have a duty to manage and conserve the estate for the remaindermen and at the same time to produce a fair return for the life tenant. Thus, trustees have a long-range financial problem to consider, which is not true of the average executor. Peculiarly, this distinction seems to work both ways. In one Pennsylvania case, ${ }^{12}$ the court, in surcharging an executor, held that the fact that he was an executor who had held securities for more than six months (the statutory period) put upon him a heavy burden of proving care. ${ }^{13}$ In another Pennsylvania case, ${ }^{14}$ however, the court seemed to consider that an executor, with his brief period of stewardship, should be regarded more leniently. ${ }^{15}$

Actually, it is necessary to find out a little more than the simple fact that an executor is involved. If there are creditors whose rights are endangered by a policy of retention, the court will usually insist on enough immediate liquidation to pay all debts. ${ }^{16}$ Some courts have attached almost as much importance to the rights of pecuniary legatees, ${ }^{17}$ although this is not nearly so clear, since the residuary legatees are also entitled to have their interests respected. ${ }^{18}$ Where the estate is clearly sufficient to pay debts and pecuniary.legacies, and the residue is to be turned over to trustees, the executors do not seem to be held to any higher standard of care than the trustees who will succeed

12. Curran's Estate, 18 Pa. D. \& C. 103 (O. Ct. 1933).

13. If the executors put up a strong enough case under the "evidence of care" factors, they will be held to have met the burden. For example, in Dauler's Estate, $247 \mathrm{~Pa}$. 356, 93 Ati. 511 (1915), the court held that retention by executors for six years was justified, where decedent had been a director of the company and there was a financial crash soon after his death, resulting in a very narrow market. In Matter of Estate of Weston, 91 N. Y. 502 (1883), executors with a duty to sell were allowed to retain because of the unusual conditions resulting from the panic of 1873 .

14. Taylor's Estate, $277 \mathrm{~Pa} .518,121$ At1. 310 (1923). The court said, at p. 526: ". . . the rule in respect to holding non-legal securities owned by a decedent, which governs executors and other personal representatives, with their presumably short-duration trusts, should, for obvious reasons, be more liberal than that governing trustees fixed with the duty of managing an estate during a long period of years."

15. See also Seamans' Estate, 333 Pa. 358, 5 A. 2d 208 (1939).

16. Elverson's Estate, 15 Pa. D. \& C. 383 (O. Ct. 1931); see also Reiley v. Healey, 122 Conn. 64, 187 Atl. 661 (1936). In Stewart's Appeal, 110 Pa. 410, 6 At1. 321 (1885), the court, in refusing to surcharge, relied on the fact that creditors' rights were not involved.

17. In Curran's Estate, 18 Pa. D. \& C. 103 (O. Ct. 1933), the fact that there were pecuniary legatees outweighed the background of decedent, the evidence of care submitted, and the fact that the securities were sound. See also Matter of Stumpp, 153 Misc. 92, 274 N. Y. Supp. 466 (Surr. Ct. 1934) and Mellier's Estate, $18 \mathrm{~Pa}$. D. \& C. 595 (O. Ct. 1933), aff'd, 312 Pa. 157, 167 At1. 358 (1933).

But cf. Matter of Kent, 146 Misc. 155, 261 N. Y. Supp. 698 (Surr. Ct. 1932), aff'd, 246 App. Div. 604, 284 N. Y. Supp. 976 (1st Dept. 1935), leave to appeal denied, 270 N. Y. 675 (1936), in which there were debts and specific legacies that nearly equalled the total assets of the estate at date of death, but the heavier burden was met by strong evidence of care.

18. Matter of Andrews, 239 App. Div. 32, 265 N. Y. Supp. 386 (2d Dept. 1933); Gardner's Estate, 323 Pa. 229, 185 Atl. 804 (1936); Borell's Estate, 256 Pa. 523, 100 At1. 953 (1917). 
them, ${ }^{19}$ and there is some indication, as can be inferred from the dictum in Taylor's Estate ${ }^{20}$ that they will actually be treated more leniently. ${ }^{21}$ However, a fair general rule to be gathered from all the cases is that only in rare situations is the trustee's burden heavier. Normally the executor will be faced with an equal or greater burden of proof of care than the trustee. How much greater will depend on the facts of the case with respect to size of the estate in relation to debts and pecuniary legacies, and to the presence or absence of a continuing trust. Also, as will be discussed later, the attitude of the beneficiaries will influence the question.

A less important "standard of care" problem is that of the professional trustee. There has been some discussion in the textbooks ${ }^{22}$ but very little in the way of court decisions, to the effect that a professional trustee (nearly always a corporation) should be held to a somewhat higher standard of care than an amateur. This is based on the theory that a professional holds himself out to the public as more capable than an amateur in handling fiduciary matters, and should therefore live up to his representations. An adequate answer would seem to be that any one who accepts a trust should accept all of the duties, and that the standard should not vary just because of the nature or character of the trustee. The professional trustee theory has received tentative acceptance in some cases, ${ }^{23}$ but has apparently been rejected in others. ${ }^{24}$

(b) Was the fiduciary retaining decedent's investments or making an investment himself?

In the "legal list" states, this question (in the absence of a discretionary power) is all-important. A trustee who has cash to invest is required to place it in investments specifically authorized by statute, If he does not do so, he becomes an insurer against loss as to the

19. Matter of Winburn, 140 Misc. 18, 249 N. Y. Supp. 758 (Surr. Ct. 1931); Mitchell's Estate, 21 Pa. D. \& C. 225 (O. Ct. 1934). But cf. Matter of Buck, 184 Misc. 29, 52 N. Y. S. $2 d 294$ (Surr. Ct. 1944), which, incidentally, can hardly be reconciled with Matter of Kent, supra note 17.

20. See note 14 supra.

21. This idea was carried out in McInnes v. Whitman, 313 Mass. 19, 46 N. E. 2d 527 (1943), in which the executor (who had also actually performed as trustee) was allowed retention without surcharge for an estimated "normal" period of estate settlement, but was then surcharged as trustee for holding beyond that time.

22. ScotT, TRUSTs, \$174.1 (1939); REsTatement, TRUSTS, \$227, comment (d) (1935); Bogert, TRUSTS aNd TRUSTEES, $\$ 541$ (1946).

23. See Estate of Busby, 288 I1l. App. 500, 6 N. E. 2d 451 (1937) ; New England Trust Co. v. Paine, 317 Mass. 542, 59 N. E. 2d 263 (1945), 320 Mass. 482, 70 N. E. 2d 6 (1946) ; Matter of Baker, 249 App. Div. 265, 292 N. Y. Supp. 122 (4th Dept. 1936); Darling Stores, Inc. v. Fidelity-Bankers Trust Co., 178 Tenn. 165, 156 S. W. 2d 419 (1941) ; Allis' Estate, 191 Wisc. 23, 209 N. W. 945 (1926).

24. Security Trust Co. v. Appleton, $303 \mathrm{Ky}$. 328, $197 \mathrm{~S}$. W. 2d 70 (1946); Matter of Flint, 240 App. Div. 217, 269 N. Y. Supp. 470 (2d Dept. 1934), aff'd, 266 N. Y. 607 , 195 N. E. 221 (1935); Linnard's Estate, 299 Pa. 32, 148 Atl. 912 (1930). 
unauthorized investments. ${ }^{25}$ If he does keep within the class, he is still required to observe the rule of prudence, ${ }^{26}$ but it would take a strong case of negligence to result in surcharge.

The situation is quite different when the fiduciary retains investments of the decedent. The courts pay lip service to the legal list rule, but the results of the decided cases show that the underlying principles of the prudent man rule have somehow crept in. At first it was said that a legal list fiduciary must dispose promptly of investments not on the list. Soon the "promptly" became "within a reasonable time." Some of the courts, particularly the Pennsylvania courts, have then given the fiduciary a surprising degree of discretion in determining what is a reasonable time. Retention has sometimes been allowed for periods of years, and one leading Pennsylvania case ${ }^{27}$ held that the only effect of the presence of retained non-legal securities in the portfolio was to place the burden of proving prudence on the fiduciary. ${ }^{28}$ New York has not gone that far, but its cases have also shown a marked sympathy for the fiduciary who is faced with the problem of when to dispose of decedent's investments. ${ }^{29}$

Although this rather liberal attitude of the courts following the legal list rule seems to bring them very close to the prudent man rule where the problem of retention is involved, it must be remembered that there is still a basic distinction between the two rules. The legal list fiduciary, operating without a discretionary power, knows that he must sell some time. The court might treat him kindly, should unusual

25. Villard v. Villard, 219 N. Y. 482, 114 N. E. 789 (1916) ; Ackerman v. Emott, 4 Barb. 626 (N. Y. Sup. Ct. 1848) ; see Matter of Buck, 184 Misc. 29, 52 N. Y. S. $2 d$ 294 (Surr. Ct. 1944); Taylor's Estate, 277 Pa. 518, 121 Atl. 310 (1923); Berges' Estate, 30 Pa. D. \& C. 549 (O. Ct. 1937).

Naturally, this is not quite true in the "permissive" States, and at least one New York case seems to have stated that the permissive rule is applicable to New York. Matter of Cady, 211 App. Div. 373, 207 N. Y. Supp. 385 (4th Dept. 1925).

26. See Matter of Flint, 240 App. Div. 217, 269 N. Y. Supp. 470 (2d Dept. 1934), aff'd, 266 N. Y. 607,195 N. E. 221 (1935); Matter of Àdriance, 145 Misc. 345,260 N. Y. Supp. 173 (Surr. Ct. 1932); Curran's Estate, 17 Pa. D. \& C. 435 (O. Ct. 1933), aff'd, 312 Pa. 416, 167 Atl. 597 (1933).

Again this rule does not apply to the "permissive" State, where the fiduciary seems to be protected in legal list investments, and again Matter of Cady, supra note 25, tries to make New York a "permissive" State.

27. Casani's Estate, 342 Pa. 468, 21 A. 2d 59 (1941).

28. Other Pennsylvania cases which have upheld retention under similar circumstances (though without going quite so far in their language) are: Miller's Estate, 345 Pa. 91, 26 A. 2d 320 (1942); Shipley's Estate, 337 Pa. 571, 12 A. 2d 343 (1940); Borell's Estate, $256 \mathrm{~Pa}$. 523, 100 Atl. 953 (1917) ; Stewart's Appeal, 110 Pa. 410, 6 Atl. 321 (1885) ; Coggins' Appeal, 3 Walker 426 (Pa. 1881); Mitchell's Estate, 21 Pa. D. \& C. 225 (O. Ct. 1934). In Taylor's Estate, 277 Pa. 518, 121 Atl. 310 (1923), there is a dictum at p. 528 to the effect that a fiduciary who retains non-legals only has the burden of showing that the retention represented an "honest exercise of judg-

29. Matter of Horton, 166 Misc. 768, 3 N. Y. S. 2d 215 (Surr. Ct. 1938) ; Matter of Kent, 146 Misc. 155, 261 N. Y. Supp. 698 (Surr. Ct. 1932), aff'd, 246 App. Div. 604,284 N. Y. Supp. 976 (1st Dept. 1935), leave to appeal denied, 270 N. Y. 675 (1936); see Matter of Adriance, 145 Misc. 345, 260 N. Y. Supp. 173 (Surr. Ct. 1932); Matter of Clark, 257 N. Y. 132, 177 N. E. 397 (1931). 
circumstances cause him to defer sale even for a long period, but he is always faced with the knowledge that he cannot retain the non-legals forever, and that every day of retention makes his risk of surcharge greater. He therefore has to give the matter of sale almost constant attention, and must submit substantial evidence of care to justify his retention. In the absence of this, or if the other standard of care factors mitigate against him, he is likely to be surcharged. ${ }^{30}$

Courts following the prudent man rule, in giving retention a special status, also seem to have departed somewhat from their own theory. One of the premises of the prudent man rule is that there is no difference between retention and investment, a thesis stated as recently as 1943 by the Massachusetts court. ${ }^{31}$ The idea behind this is that the trustee is given discretion. Unlike the legal list trustee, if he sells he may purchase anything that a prudent man would buy, so that investment, to him, therefore should be the same as retention, and should call for the same standard of care. However, the theory has not been carried out in practice. An examination of the cases will indicate that the proportion of investment surcharges to retention surcharges is very high when contrasted to the proportion of investment cases to retention cases.

There is sound reason for this result. In the first place, the background of the decedent ${ }^{32}$ is bound to have an influence. In addition to this, it is widely agreed among investments experts as well as laymen that sale of a security involves more consideration than refusal to buy the same security: positive rather than negative action is required, and the seller must possess a definite reason to sell, not simply a lack of reason not to sell. This distinction between retention and

30. Lewis' Estate, $344 \mathrm{~Pa} .586,26 \mathrm{~A} .2 \mathrm{~d} 445$ (1942) ; Berges' Estate, $30 \mathrm{~Pa}$. D. \& C. 549 (O. Ct. 1937); Curran's Estate, 18 Pa. D. \& C. 103 (O. Ct. 1933); Seaman's Estate, $333 \mathrm{~Pa}$. 358, 5 A. 2d 208, 211 (1939), where the court described the limitation on the right of a legal list fiduciary to retain non-legals as follows:

'The law imposes limitations upon 'ordinary prudence' in such cases in order to preserve the differentiation between nonlegal and legal securities, and between fiduciaries and others as to the right to speculate. The mere fact that a trustee may honestly believe that an unauthorized security will appreciate in value at some more or less remote period is not sufficient justification for his retention of it in the trust estate, and 'common prudence' or 'normally good judgment' must not be deemed to confer such latitude of discretion."

Matter of Baker, 249 App. Div. 265, 292 N. Y. Supp. 122 (4th Dept. 1936). In re Hamersley's Estate, 180 N. Y. Supp. 887 (Surr. Ct. 1920) and Matter of Yung, 103 Misc. 358, 170 N. Y. Supp. 303 (Surr. Ct. 1918) indicate that there is an automatic surcharge for retention of non-legals; this is opposed to the cases cited in note 29 stipra, and is certainly not the law in New York. In addition, these cases involve strong evidence of negligence.

31. McInnes v. Whitman, 313 Mass. 19, 46 N. E. $2 d 527$ (1943). Accord, Kinmouth v. Brigham, 5 Allen 270 (Mass. 1862).

32. See discussion and cases infra, pp. 659-660. See also Security Trust Co. v. Appleton, $303 \mathrm{Ky} .328,197 \mathrm{~S}$. W. 2d 70 (1946); North Adams National Bank v. Curtiss, 278 Mass. 471, 180 N. E. 217 (1932). Note also that in McInnes $v$. Whitman there were no other standard of care factors to help the trustee and that in Kinmonth v. Brigham the retained investment was quite speculative. 
investment is illustrated not only by the "decedent's background" cases but also by the diversification cases..$^{33}$ Finally, a very real legal theory has been developed by a line of Massachusetts cases; starting with Bowker v. Pierce. ${ }^{34}$ This theory is that retention of a sound security on a steadily falling market is difficult to criticize. There we have not only the retention factor but also the "hard times" which always makes courts sympathetic to the baffled fiduciary. So, although language to the contrary is occasionally found, it can safely be said that the prudent man courts do distinguish between retention and investment, and that the fiduciary has a better chance in the former case than in the latter.

It would appear, then, that the legal list states, while bound by the statute in investment cases, incline toward the prudent man approach in retention cases. The prudent man states, while in a sense pretending to recognize no distinction between investment and retention, actually do give different treatment to the two problems, thus recognizing in some measure the much more marked distinction drawn by the legal list courts. In either type of state, the retaining fiduciary is not required to live up to such a high standard of care as is the investing fiduciary.

\section{(c) What discretionary powers were contained in the trust instrument?}

This factor is obviously of great importance in determining the standard of care. Any court, in passing upon the actions of a fiduciary, will look at once at the instrument giving him his powers. The first duty of the probate court is to carry out any wishes of the decedent that do not conflict with public policy. If the directions in the trust instrument are explicit enough, they can control the case absolutely, in the absence of bad faith or such gross negligence that public policy would be offended by an exoneration. ${ }^{35}$ The directions are rarely that specific, with the result that there has been built up in both prudent man and legal list states a considerable body of law concerning the effect of various clauses commonly found in trust instruments.

33. See notes 90,92 infra.

34. 130 Mass. 262, 264 (1881) :

"We can now see that it would have been wiser to sell the stock. But in judging his acts, we should put ourselves in his position at the time. He was considering the question, not whether he should invest in the stock, but whether he should sell the stock bought by the testator, upon a falling market."

Accord, Kimball v. Whitney, 233 Mass. 321, 123 N. E. 665 (1919); Green v. Crapo, 181 Mass. 55, 62 N. E. 956 (1902).

35. See the "exculpatory clause" cases cited in note 108 infra. This logic would apply with almost equal force where there was a specific direction to sell, purchase or retain a certain security. Cf. Nelligan v. Long, 320 Mass. 439, 70 N. E. 2d 175 (1946); First National Bank of Boston v. Truesdale Hospital, 288 Mass. 35, 192 N. E. 150 (1934). 
In a legal list state, a discretionary power is given great consideration. A power to invest in "non-legals" radically alters the entire picture of the administration, and probably gives the fiduciary even greater opportunity for exercise of discretion than the trustee has in a prudent man state. ${ }^{36}$ Because of the comparative liberality of the legal list courts in a retention case, even in the absence of an express power to retain, the effect of such a retention power is not quite so noticeable on the surface as that of a power to invest. In some cases it is said that all it does is shift the burden of proof; ${ }^{37}$ others give it considerably more weight. ${ }^{38}$ But irrespective of what the courts say, their holdings are clear: the legal list cases are almost unanimous in having refused to surcharge a fiduciary who retained under a power. Naturally this does not mean that it could not be done or that it has not been done, ${ }^{39}$ but the actual results are nonetheless impressive, and indicate the great respect the courts have for the expressed wishes of the decedent.

36. In Detre's Estate, 273 Pa. 341, 117 Atl. 54 (1922), the court said at p. 350, in refusing to surcharge for a non-legal investment:

"Furthermore, a trustee will not be held personally liable for an honest exer-

cise of a discretionary power, in the absence of supine negligence or wilful default."

Accord, Matter of Beadleston, 146 Misc. 548, 262 N. Y. Supp. 507 (Surr. Ct. 1933) ; Clay's Estate, 25 Pa. D. \& C. 257 (O. Ct. 1936). In King v. Talbot, 40 N. Y. 76 (1869), a discretionary power was held ineffective to add to the trustee's powers; later cases seem to have interpreted this to mean that the particular power granted was not sufficient. Certainly the New York cases now give full weight to a discretionary investment power. See cases cited in Note, 99 A. L. R. 909, 912 et seq. (1935).

37. Glauser's Estate, 350 Pa. 192, 38 A. 2d 64 (1944); Stirling's Estate, $342 \mathrm{~Pa}$. 497, 21 A. 2 d 72 (1941) ; Clay's Estate, 25 Pa. D. \& C. 257 (O. Ct. 1936).

Although the will apparently contained an exculpatory clause, the court in Matter of Clark, 257 N. Y. 132,177 N. E. 397 (1931) went only so far as to say that there must (for surcharge) at least be evidence of lack of reasonable care.

38. Brown's Estate, $287 \mathrm{~Pa}$. 499, 135 Atl. 112 (1926); Bartol's Estate, $182 \mathrm{~Pa}$. 407, 38 Atl. 527 (1897). In Jones' Estate, 344 Pa. 100, 23 A. 2d 434 (1942) the court first said that the power to retain shifted the burden of proof, then seemed to apply the "supine negligence" rule. In Dempster's Estate, 308 Pa. 153, 162 Atl. 447 (1932), the power to retain, combined with a narrow market and decedent's background, was sufficient to overcome the fact that the securities retained were such as would normally be frowned on by either a legal list or prudent man court. These factors, though given different emphasis between themselves, would probably have caused the same result in Massachusetts.

Edward's Estate, 6 Pa. D. \& C. 121 (O. Ct. 1925) puts the effect of the power to retain on what seems to be its most logical basis when the court says, at p. 123:

"The liability of the trustee in cases of retention of the testator's investments must, therefore, be the same as it would be if he, without any testamentary provisions on the subject, had invested in the classes of securities specified in the act of assembly. If this be so, it follows that the responsibility of the trustee must be measured by his exercise of such diligence and care as a man of ordinary prudence would practice in the care of his own estate."

In the Matter of Winburn, 140 Misc. 18, 20, 249 N. Y. Supp. 758, 762 (Surr. Ct. 1931), the court said:

"Such provisions [absolving of duty to sell] are in themselves protection to these executors unless there is proof of fraud or gross negligence."

39. For example, in Matter of Booth, 147 Misc. 353, 264 N. Y. Supp. 773 (Surr. Ct. 1933), the court surcharged despite a power to retain. Although the court does not indicate what effect the power to retain had, it was not enough to overcome the failure of the fiduciary to sell when its own committee recommended sale. In this case it could be said that the standard of care was low (as is indicated by the very slight 
These results in a legal list state might be said to be natural; bars were erected by the legislature, but they could be torn down by the decedent; when torn down, they are torn all the way down. In a prudent man state this rationale would not apply. There the fundamental rule of trust administration gives to the fiduciary an ample discretion so that any words of the decedent giving him discretion would therefore seem to be repetitious and neither add to his power nor detract from the possibility of liability. Where investment is concerned, at least a few cases bear this out. ${ }^{40}$ Where retention is involved, it has been said that the only helpful clause is an exculpatory one, ${ }^{41}$ but the cases seem to contradict this, and to give real weight to a power to retain. ${ }^{42}$

From the above, the conclusion can be drawn that the best defense with which a legal list trustee can start off is a discretionary power. Where there is one, the burden on the beneficiary is very heavy, and a strong case of negligence must be presented. The effect of such a power is not quite so great in a prudent man state, but it is still an important factor, and a court is likely to require of the beneficiary a

evidence of care needed to absolve the fiduciary for retaining other investments) but that the action of the fiduciary did not measure up even to that standard.

However, in Matter of Clark, 257 N. Y. 132,177 N. E. 397 (1931), the failure of a trustee operating under an exculpatory clause (which was treated by the court about as a power to retain would be) to sell after its own committee recommended sale, did not result in surcharge.

40. Davis, Appellant, 183 Mass. 499, 67 N. E. 604 (1903) ; accord, Mattocks v. Moulton, 84 Me 545, 24 Atl. 1004 (1892); St. Germain's Adm'r. v. Tuttle, 114 Vt. 263, 44 A. 2d 137 (1945). But see Brown v. French, 125 Mass. 410 (1878).

41. Shattuck, The Massachusetts Prudent Man in Trust Investments, 25 B. U. L. REv. 307, 341 (1934), says :

ing rule."

This statement seems to be meant to apply to powers to retain as well as powers to invest. Scott distinguishes between powers to retain and powers to invest, giving the former greater weight. 2 ScoTT, TRUSTS, $\$ \S 227.14,230.1$ (1939).

42. Although no specific discretionary power was given in Harvard College v. Amory, 9 Pick. 446 (Mass. 1831), the will indicated great confidence in the trustee, and the court in relying upon this fact said, at p. 461 :

"These trustees are not to be made chargeable but for gross neglect and wilful mismanagement."

Note similarity of this statement with the one made by the Pennsylvania court in Detre's Estate, $273 \mathrm{~Pa}$. 341, 117 Att. 54 (1922), cited supra note 36.

A power to retain "stock in mining companies and any other securities or property of any kind which may be found in my estate" was given effect in Old Colony Trust Co. v. Shaw, 261 Mass. 158, 158 N. E. 530 (1927), even though 9/13ths of the estate was in securities normally considered improper.

In In re McCann's Will, 212 Minn. 233, 3 N. W. $2 d 226$ (1942), the will contained exculpatory words, but the court construed the clause as a power to retain and gave effect to it as such. The decisions in Peck v. Searle, 117 Conn. 573, 169 Atl. 602 (1933) and Fairleigh v. Fidelity National Bank \& Trust Co., 335 Mo. 360, 73 S. W. 2d 248 (1934) and a dictum in North Adams National Bank v. Curtiss, 278 Mass. 471, 180 N. E. 217 (1932) also support this view.

Where the power is specifically directed to a given investment, an even stronger case is presented, and there is no question but that the power will be given considerable weight in a prudent man State. Nelligan v. Long, 320 Mass. $439,70 \mathrm{~N}$. E. 2d 175 (1946); First National Bank of Boston v. Truesdale Hospital, 288 Mass. 35, $192 \mathrm{~N}$. E. 150 (1934). 
better case than it would if no power were present. This is particularly true where a retention under a power to retain is involved.

\section{(d) What was the decedent's background?}

On this issue there might be some fine theoretical distinction between the legal list and prudent man states, arising from the argument that prudent man states give discretion anyway and that it cannot be enlarged by such a thing as background of the decedent. If so, it is not visible to the naked eye. All courts recognize and place great emphasis upon this factor. The ultimate facts that are usually considered important are: (a) that decedent had been active in the industry or corporation in question, and/or (b) that decedent as an investor had shown great confidence in the industry or corporation.

The cases, starting with Harvard College v. Amory, abound with illustrations of both of these situations. ${ }^{43}$ It rarely happens that a trustee is surcharged where he can show that he retained a security in a company in which decedent had been very active during his lifetime. The case is not quite so strong where decedent had only the confidence of an investor, but the fact that he had placed unusual confidence in a particular company or industry is always given weight by the courts.

The usual way of proving this background is by indirect testimony-evidence of decedent's activities during his life. However, more direct testimony is also admissible, always (at least theoretically) simply to show the background, though not to vary the terms of the will. Letters of the decedent have been admitted for this purpose, ${ }^{44}$ and even testimony of oral statements. ${ }^{45}$

The rationale of this seems at first to be somewhat elusive, but actually is not. It can be argued that the fiduciary is governed only by the will and by normal standards of conduct, that he is just as negligent in retaining decedent's pet investment as he is in buying or retaining any other investment, and that the same standard should

43. Actively-Poor v. Hodge, 311 Mass. 312,41 N. E. $2 d 21$ (1942); In re McCann's Will, 212 Minn. 233, 3 N. W. 2d 226 (1942) ; Warmack v. Crawford, 195 S. W. 2d 919 (Mo. 1946) ; Fairleigh v. Fidelity National Bank \& Trust Co., 335 Mo. 360, 73 S. W. 2d 248 (1934); Matter of Easton, 178 Misc. 611, 35 N. Y. S. 2d 546 (Surr. Ct. 1942), aff'd, 41 N. Y. S. 2 d 190 (4th Dept. App. Div. 1943).

Investor-Stevens v. Meserve, 73 N. H. 293, 61 Ati. 420 (1905) ; Matter of Winburn, 140 Misc. 18, 249 N. Y. Supp. 758 (Surr. Ct. 1931) ; Coggins' Appeal, 3 Walker 426 (Pa. 1881); Peckham v. Newton, 15 R. I. 321, 4 Atl. 758 (1886); see North Adams National Bank v. Curtiss, 278 Mass. 471, 180 N. E. 217 (1932) and Stewart's Appeal, 110 Pa. 410, 6 Atl. 321 (1885).

44. In re McCann's Will, 212 Minn. 233, 3 N. W. $2 d 226$ (1942) ; Matter of Ryan, 186 Misc. 688, 57 N. Y. S. 2 d 462 (Surr. Ct. 1945); Matter of Estate of Weston, 91 N. Y. $502(1883)$.

45. Poor v. Hodge, 311 Mass. 312, 41 N. E. 2d 21 (1942); Matter of Balfe, 152 Misc. 739, 274 N. Y. Supp. 284 (Surr. Ct. 1934), mod., 245 App. Div. 22, 280 N. Y. Supp. 128 (2d Dept. 1935). 
apply to each. One possible answer is that evidence of what prudent men thought about the company is admissible; if decedent had been successful, why not admit this evidence to show what he, as a prudent man, thought? This answer, however, if valid at all, is certainly not enough to entitle the evidence, if admitted, to be given much weight. ${ }^{46}$ Conditions on which decedent relied inevitably change, the management in which he had confidence, and of which he might have been a part, also changes; what he thought ten or twenty years ago as to the soundness of a security would have little if any probative value in itself.

The true answer seems to be that the fiduciary is, after all, trying to carry out the wishes of the decedent; he is trying to be the "other self" of the decedent, and to continue, so long as they seem sound, the investment policies that made the decedent a success. The will is his first guide, and he must always bear in mind the policies of the court and state which appointed him. But he is also entitled to judge his policies in the light of what he would normally expect the decedent's wishes to be. ${ }^{4 \tau}$ Of course, this does not give him the right to go blindly along, irrespective of what happens in the financial and business world, but it does give him more leeway than a trustee of a so-called "normal" trust would have. It must be remembered that investment policy is largely guesswork; where there is reasonable cause for doubt as to what steps to take, the benefit of that doubt is more likely to be given to that trustee who tried to do what he thought the decedent would have done under similar circumstances. As was said in Harvard College v. Amory, at p. 462, "The circumstance of the trustees' reposing confidence where the testator had, is one which is always to be considered as tending properly to their discharge."

\section{(e) Did the fiduciary act in good or bad faith?}

This would appear to be an extraordinary element to list under "standard of care" factors. Every fiduciary is compelled to act in good faith; the fact that he did should not entitle him to any particular respect or make the court feel particularly kindly toward him. If he acted in bad faith, he should be an insurer against loss arising from that action. ${ }^{48}$ However, it is not all black or white. A corporate

46. The weight would, of course, vary with the circumstances, depending on the period of time involved, the degree of change in management and circumstances, etc.

47. Matter of Estate of Weston, 91 N. Y. 502 (1883).

48. See Ball v. Hopkins, 268 Mass. 260, 167 N. E. 338 (1929) ; Loring, A TrusTEE's HANDBOOK, $\$ \$ 18,19$ (Shattuck's ed. 1940). See also Matter of Stumpp, 153 Misc. 92, 274 N. Y. Supp. 466 (Surr. Ct. 1934), where the court, in surcharging, relied almost entirely on the improper motive of the executors in retaining in order to enhance the possibility of gain to themselves. In addition the court was apparently influenced by the bad faith of the executors with respect to the creditors of one of them. 
trustee which purchases its own stock, or borrows from itself, might show that it did so in good faith, but there would still be a stigma attached to the action, and the trustee's burden becomes correspondingly heavier. ${ }^{49}$ On the other hand, in some cases trustees have shown so positively that their actions were performed in the utmost good faith, with only the best interests of the beneficiaries behind them, that the courts have seemed inclined to be somewhat more lenient simply because of this positive proof, rather than bland assumption, of good faith. ${ }^{50}$ Naturally this would not go far toward discharging the fiduciary, but the shadings are sometimes delicate, and it might make some difference in a close case.

\section{(f) Was there some acquiescence by the complaining parties, though not enough to create an estoppel?}

If it seems illogical to treat good or bad faith as a "standard of care" factor, it is surely doubly so to put acquiescence in that category. Technically, acquiescence is an affirmative defense. If it has been shown that the fiduciary has not measured up to the standard of care required of him and is therefore prima facie liable for the resulting loss, he can then prove that the parties in interest acquiesced in the unfortunate decisions and thus avoid liability. This is, in effect, a defense of estoppel. If he should fail to prove the estoppel, it would seem that the evidence he has introduced on the subject should be given no weight at all. However, the law has not gone that far. In some cases

49. In re Sanford, 297 N. Y. 64, 74 N. E. 2d 310 (1947) ; City Bank Farmers' Trust Co. v. Cannon, 291 N. Y. 125, 51 N. E. 2d 674 (1943); Matter of Junkersfeld, 244 App. Div. 260, 279 N. Y. Supp. 481 (2d Dept. 1935); Matter of Hirsch, 116 App. Div. 367, 101 N. Y. Supp. 893 (1st Dept. 1906), aff'd, 188 N. Y. 584, 81 N. E. 1165 (1907); Berges' Estate, 30 Pa. D. \& C. 549 (O. Ct. 1937).

In Casani's Estate, $342 \mathrm{~Pa} .468,21 \mathrm{~A} .2 \mathrm{~d} 59$ (1941) the decision might well have been different because of this factor. A dissent pointed out that the individual trustee was a remainderman, and had expressed himself as refusing to sell, irrespective of corporate position, until the stocks returned to their inventory value. The majority apparently ignored this testimony in absolving the trustee.

In Matter of Balfe, 152 Misc. 739, 274 N. Y. Supp. 284 (Surr. Ct. 1934), mod., 245 App. Div. 22, 280 N. Y. Supp. 128 (2d Dept. 1935), the trustee held its own stock and also purchased mortgages from itself. However, these considerations were balanced by others, such as decedent's background and a power to retain, and the evidence showed both care and prudence. In Greenawalt's Estate, $343 \mathrm{~Pa}$. 413, $21 \mathrm{~A}$. 2d 890 (1941), retention of trustee's stock was at least balanced by the power to retain and the fact that the loss was due primarily to the depression.

50. Bowker v. Pierce, 130 Mass. 262 (1881) ; In re McCann's Will, 212 Minn. 233 , $3 \mathrm{~N}$. W. 2d 226 (1942) (trustees held substantial interests in same company, received no compensation as trustees); Matter of Estate of Weston, $91 \mathrm{~N}$. Y. 502 (1883) (executor held same stock individually); Dempster's Estate, $308 \mathrm{~Pa} .153,162$ Atl. 447 (1932) ; Stewart's Appeal, $110 \mathrm{~Pa}$. 410, 6 At1. 321 (1885) (sold own stock at same time); see also Coggins' Appeal, 3 Walker 426 ( $\mathrm{Pa}$. 1881).

In Jenks' Estate, 19 Pa. D. \& C. 479 (O. Ct. 1933), the executor was commended for lending the estate money in order to close out a margin account. This is the type of self-dealing which is frequently subjected to criticism, but here the good faith indicated actually influenced the court the other way. 
acquiescence has been held to be a complete defense; ${ }^{51}$ usually the court has found acquiescence without determining definitely whether or not there would have been a surcharge if acquiescence had been missing. In at least one case ${ }^{52}$ the court has followed this logic to its ultimate conclusion and surcharged on a percentage basis, holding the trustee liable to those who had not acquiesced, not liable to those who had.

In a number of cases, however, acquiescence will be mentioned and apparently relied upon in part by the court in refusing to surcharge. In some of these cases there simply is not sufficient evidence of acquiescence to set up an estoppel; in others, it appears that there are some parties in interest who have not, or could not have, acquiesced. To be completely logical in the latter type of case, the court should apply percentages or, if it be remaindermen who have not acquiesced, set up a separate fund for them from the surcharge money, letting the income go to the surcharged trustees until the remainders come in. ${ }^{53}$ In both types of case, the courts have seemed to use acquiescence along with other factors in refusing to surcharge. ${ }^{54}$ The only way this can be rationalized is by saying that, where the active beneficiaries acquiesce, or appear to acquiesce, the discretion of the trustees is somewhat broader. Thus, by a back door route, partial acquiescence can conceivably lower the standard of care. Conversely, a demand for sale raises the standard of care. The fiduciary, after receiving such a demand, still has the duty of exercising his own judgment, but he is put on notice that at least one party in interest thinks he should sell, and his refusal places upon him a heavier burden of proving care and prudence. ${ }^{55}$

51. Clabby's Estate, $338 \mathrm{~Pa} .305,12$ A. 2d 71 (1940); Stephens' Estate, $320 \mathrm{~Pa}$. 97, 181 Atl. 559 (1935); Brown's Estate, 287 Pa. 499, 135 At1. 112 (1926). In City Bank Farmers' Trust Co. v. Cannon, 291 N. Y. 125, 51 N. E. $2 d 674$ (1943), it was held that acquiescence by a settlor with a power to revoke was a good defense even against an infant remainderman.

52. McInnes v. Whitman, 313 Mass. 19, 46 N. E. 2d 527 (1943).

53. In Matter of Junkersfeld, 244 App. Div. 260, 279 N. Y. Supp. 481 (2d Dept. 1935), an acquiescing widow was estoppped as to her $1 / 3$ share of the residue of the estate, but was allowed to share as an income beneficiary of the trust, although as coexecutor she was surcharged along with the trust company. It is submitted that she should not have been allowed to benefit from the surcharge at all, but should have received (as payer of $1 / 2$ the surcharge) only one-half of the additional income resulting from the surcharge, the other half going to the surcharged trustee. There are several ways in which this could have been worked out.

54. Gardner's Estate, $323 \mathrm{~Pa} .229,185$ Atl. 804 (1936); Fairleigh v. Fidelity National Bank \& Trust Co., 335 Mo. 360,73 S. W. 2d 248 (1934); Green v. Crapo, 181 Mass. 55, 62 N. E. 956 (1902); see Greenawalt's Estate, 343 Pa. 413, 21 A. $2 d 890$ (1941).

In Casani's Estate, $342 \mathrm{~Pa} .468,21 \mathrm{~A} .2 \mathrm{~d} 59$ (1941), the court said, at p. 470 :

"The field of investment defined by the statute may be enlarged by the will, by acquiescence of beneficiaries, or in certain cases by order of court."

55. Mellier's Estate, 18 Pa. D. \& C. 595 (O. Ct. 1933), aff'd, 312 Pa. 157, 167 Atl. 358 (1933). In Bowker v. Pierce, 130 Mass. 262 (1881) this heavier burden was held to have been met. 


\section{B. Evidence of Care}

It would simplify things considerably if, having examined the factors making up the standard of care in a particular case, we could state exactly what the standard was and apply the evidence of care with mathematical precision to arrive at a result demonstrably accurate. Unfortunately, trust surcharge law is too much a question of degree to allow for this. However, we do at least have something to go by in examining the evidence of care and prudence; we should be able to tell whether this fiduciary is to be measured by a normal standard, or by one higher or lower than normal. If, for example, we have a legal list trustee with no powers in the will, who retained for a long time stock that decedent was not particularly interested in, he will have to show by convincing evidence that he acted with unusual care and used sound judgment. If, on the other hand, the same trustee had a power to retain, and the stock held was in the company which had built decedent's fortune, he will have a great deal more leeway, and a very strong case of negligence would have to be presented to result in surcharge.

Having arrived at a determination of what the standard of care is to be, we must next examine the fiduciary's actions to see whether they measured up to it. This in turn breaks down into two sections: whether he has, in making his decisions, done the precautionary things that a fiduciary should have done, and whether his actual decisions, based upon his findings, were sound ones for a fiduciary to make. The distinction between these two questions, though not often made specifically by the courts, ${ }^{56}$ is nonetheless important. The chief reason for this is that the standard of care factors probably have little bearing on the first but very decided influence on the second. In other words, a fiduciary can rarely, if ever, afford to be lazy, but he sometimes can get by with stupidity, or with what would be held to be stupid, or at least imprudent, if done by another fiduciary under circumstances differing from those surrounding the estate or trust he is administering. ${ }^{57}$

56. Two cases that have made this distinction are Reiley v. Healey, 122 Conn. 64, 187 At1. 661 (1936) and Dickinson's Estate, 21 Pa. D. \& C. 247 (O. Ct. 1934), aff'd, $318 \mathrm{~Pa} .561,179$ At1. 443 (1935). In the Reiley case the court held that there was little evidence of actual care, but then said that the conclusion on that point was unimportant as the crucial question was whether the decision was prudent. This is probably not law anywhere. The Dickinson case puts it on a much sounder basis, the court saying (p. 250):

". . the trustee . . . will be liable to a surcharge only for a failure to

study carefully the circumstances and conditions that controlled the value of the investments, or, if he has made such a careful study, for failure to act intelligently with respect thereto."

57. The best illustration of this is a case where, because of a power in the will or decedent's background, a fiduciary is allowed to retain a security he normally would be surcharged for retaining. See note 81 , infra. 


\section{(1) Has the Fiduciary Given the Estate or Trust Proper Care and Attention?}

Here is where we get the real evidence of care. No matter how broad the standard, the fiduciary must show that he did not simply let things slide or make wild, unreasoned guesses. This seems equally important under either rule, although the prudent man rule might pretend to lay somewhat greater emphasis on it. The theory behind this has been stated before: that the discretion given by the prudent man rule makes the other standard of care factors not quite so important, and the evidence of care more important than in legal list states. As has been shown, the cases have not borne this out, and it will even be found that most of the cases which go into the actual evidence of care with thoroughness are legal list cases.

There are many things a competent fiduciary should do. $\mathrm{He}$ should examine the portfolio with care, inspect the trust instrument, determine the decedent's objectives, and then shape his policy accordingly. He should study business and market conditions, ${ }^{58}$ and the records and reports of the corporation or corporations in which he is interested. ${ }^{59}$ He should, if possible, avail himself of inside information concerning the corporation. ${ }^{60} \mathrm{He}$ should consult with sound and experienced investors, ${ }^{61}$ and should study the leading financial periodicals and investment services. ${ }^{62}$ He should, at least as a matter of courtesy and probably as a matter of caution, consult with the beneficiaries and ascertain their desires. ${ }^{63}$ A corporate fiduciary should have an investment or finance committee which includes financial

58. Matter of Parsons, 143 Misc. 368, 257 N. Y. Supp. 339 (Surr. Ct. 1932), mod., 238 App. Div. 883, 262 N. Y. Supp. 957 (3d Dept. 1933); Casani's Estate, 342 Pa. 468, 21 A. 2d 59 (1941); Mitchell's Estate, 21 Pa. D. \& C. 225 (O. Ct. 1934).

59. Brown v. French, 125 Mass. 410 (1878); Matter of Bunker, 184 Misc. 316, 56 N. Y. S. 2d 746 (Surr. Ct. 1944) ; Matter of Kent, 146 Misc. 155, 261 N. Y. Supp. 698 (Surr. Ct. 1932), aff'd, 246 App. Div. 604, 284 N. Y. Supp. 976 (1st Dept. 1935), leave to appeal denied, 270 N. Y. 675 (1936) ; Jones' Estate, 344 Pa. 100, 23 A. 2d 434 (1942) ; Stirling's Estate, $342 \mathrm{~Pa} .497,21 \mathrm{~A} .2 \mathrm{~d} 72$ (1941) ; Bartol's Estate, $182 \mathrm{~Pa}$. 407, 38 Atl. 527 (1897); Scoville v. Brock, 81 Vt. 405, 70 Atl. 1014 (1908). See Taft v. Smith, 186 Mass. 31, 70 N. E. 1031 (1904).

60. Matter of Clark, 257 N. Y. 132, 177 N. E. 397 (1931) ; Jones' Estate, 344 Pa. 100, 23 A. $2 d 434$ (1942) ; Dickinson's Estate, 21 Pa. D. \& C. 247 (O. Ct. 1934), aff'd, 318 Pa. 561, 179 At1. 443 (1935); Mitchell's Estate, 21 Pa. D. \& C. 225 (O. Ct. 1934).

61. Kimball v. Whitney, 233 Mass. 321, 123 N. E. 665 (1919) ; Brown v. French, 125 Mass. 410 (1878); Stevens v. Meserve, 73 N. H. 293, 61 At1. 420 (1905); Matter of Bunker, 184 Misc. 316, 56 N. Y. S. 2d 746 (Surr. Ct. 1944); Matter of Horton, 166 Misc. 768, 3 N. Y. S. 2 d 215 (Surr. Ct. 1938) ; Casani's Estate, 342 Pa. 468, 21 A. 2d 59 (1941); Scoville v. Brock, 81 Vt. 405, 70 Atl. 1014 (1908).

62. Matter of Bunker, 184 Misc. 316, 56 N. Y. S. 2 d 746 (Surr. Ct. 1944) ; Matter of Kent, 146 Misc. 155, 261 N. Y. Supp. 698 (Surr. Ct. 1932), aff'd, 246 App. Div. 604,284 N. Y. Supp. 976 (1st Dept. 1935), leave to appeal denied, 270 N. Y. 675 (1936) ; Stirling's Estate, 342 Pa. 497, 21 A. $2 d 72$ (1941).

63. Gardner's Estate, 323 Pa. 229, 185 Atl. 804 (1936) ; Bartol's Estate, $182 \mathrm{~Pa}$ 407, 38 Atl. 527 (1897) ; but see Matter of Junkersfeld, 244 App. Div. 260, 279 N. Y. 
experts and which holds frequent meetings at which corporate securities and estate portfolios are reviewed. ${ }^{64}$ Any other evidence of care would, of course, be admissible, as would any evidence that the fiduciary had acted in a careless or slipshod manner.

Any given case is hardly likely to involve all of the above types of evidence. However, the more positive evidence of this nature submitted by the fiduciary, the better are his chances of avoiding surcharge. By the same token, positive evidence of carelessness, or even lack of evidence of care, is very likely to lead to surcharge. ${ }^{65}$

\section{(2) Were the Fiduciary's Decisions Prudent Ones?}

In considering this problem, the most important thing to remember at the outset is that hindsight can never validly be applied. Many investment decisions appear ridiculous years after they were made, but that is no criterion. The actions taken must be judged in the light of the circumstances then existing and opinions then prevalent. This is axiomatic, and has frequently been expressed by the courts in graphic language. ${ }^{66}$

Supp. 481 (2d Dept. 1935), where the positive wishes of the widow were given no weight as against the other beneficiaries.

Consultation with beneficiaries should not be relied upon too strongly, as the wishes of the life tenant are likely to be opposed to the interests of the remaindermen. See the wasting asset cases, such as Creed v. McAleer, 275 Mass. 353, 175 N. E. 761 (1931).

64. Matter of Balfe, 152 Misc. 739, 274 N. Y. Supp. 284 (Surr. Ct. 1934), mod., 245 App. Div. 22, 280 N. Y. Supp. 128 (2d Dept. 1935) ; Jones' Estate, 344 Pa. 100, 23 A. $2 d 434$ (1942); Stirling's Estate, 342 Pa. 497, 21 A. 2d 72 (1941); Mitchell's Estate, $21 \mathrm{~Pa}$. D. \& C. 225 (O. Ct. 1934). In Matter of Clark, 257 N. Y. 132, 177 N. E. 397 (1931), the committee met every six months. The court emphasized the high calibre of the men on the committee, as evidence of the trustee's prudence.

Where, however, the committee had frequent meetings in the first few months of the administration, but then had no meeting in which the estate was considered for two and a half years, it was held to be gross negligence-Matter of Junkersfeld, 244 App. Div. 260, 279 N. Y. Supp. 481 "(2d Dept. 1935).

65. In re Ward's Estate, 121 N. J. Eq. 555, 192 Atl. 68 (Prerog. Ct. 1936), aff'd, 121 N. J. Eq. 606, 191 At1. 772 (Ct. Err. \& App. 1937); Matter of Junkersfeld, 244 App. Div. 260, 279 N. Y. Supp. 481 (2d Dept. 1935) ; Blish Trust, 350 Pa. 311, 38 A. 2d 9 (1944); Seaman's Estate, 333 Pa. 358, 5 A. 2d 208 (1939).

In Kelch's Estate, $21 \mathrm{~Pa}$. D. \& C. 204 (O. Ct. 1934), aff'd by divided contrt, 318 $\mathrm{Pa} .296,178$ At1. 129 (1935), the court based its surcharge almost entirely on the lack of evidence of care, concluding that the loss resulted from lack of attention:

"It is most apparent that the trustees, so content with the high character

of the securities and their mechanical and high revenue yield, did nothing. Action became atrophied."

66. Shipley's Estate (No. 1), $337 \mathrm{~Pa} .571,12$ A. 2d 343 (1940), ("There is no rule of law which requires that an executor's foresight must measure up to the standard of a legatee's hindsight.") ; Matter of Andrews, 239 App. Div. 32, 265 N. Y. Supp. 386 (2d Dept. 1933) ("Even the witless fool may pose as a paragon of wisdom after the unforeseeable disaster has occurred") ; First National Bank of Boston v. Truesdale Hospital, 288 Mass. 35, 192 N. E. 150 (1934) ("The trend of a market is notoriously hard to discover except in retrospect. At every level skilled observers are apt to disagree as to its probable course").

Accord, Green v. Crapo, 181 Mass. 55, 62 N. E. 956 (1902) ; Matter of Clark, 257 N. Y. 132, 177 N. E. 397 (1931); Matter of Balfe, 152 Misc. 739, 274 N. Y. Supp. 284 (Surr. Ct. 1934), mod., 245 App. Div. 22, 280 N. Y. Supp. 128 (2d Dept. 1935). 
With hindsight ruled out, it is obvious that the question to be considered here is whether the decisions were prudent ones in the light of circumstances existing at the time they were made. There is a hint of causation in this question: there is some logic in stating that a fiduciary who was negligent in failing to meet the tests of actual care should not be surcharged if a more careful fiduciary would have done exactly the same thing. ${ }^{67}$ However, the courts have rarely taken this approach, but rather have considered the factors bearing on this question along with the actual proof of care.

A list of the many elements that would have some bearing in determining whether a decision had been wise or unwise would be practically endless; any relevant evidence, if not too remote, would be admissible. The factors which have been given some weight in the decided cases can be generally listed under one of the six headings which are discussed below.

\section{(a) What were other prudent people doing and saying?}

It has already been noted ${ }^{68}$ that one of the things a fiduciary should do is find out what other prudent people were doing and saying. Whether he was wise in the decision he ultimately made would seem to depend, in some measure at least, on whether his actions conformed to the best investment judgment of the day. He can show that company officials, ${ }^{69}$ investment services, ${ }^{70}$ or other leaders in the investment field ${ }^{71}$ advised the action he took, and that sound investors took

The necessity of this rule against hindsight is nowhere better emphasized than by the horrible example of the New Jersey judge who, looking back at the catastrophic 1929 market break, said :

"It was common knowledge not only amongst bankers and trust companies

but the general public as well, that the stock market condition at the time of the

testator's death was an unhealthy one, that values were very much inflated, and that a crash was almost sure to come.",

In re Chamberlain, 9 N. J. Misc. 809, 810, 156 At1. 42, 43 (Prerog. Ct. 1931). Fortunately for trustees who were not so all-seeing in 1929 as was this judge in 1931, this comment was later emphatically disapproved by the highest court of New Jersey, in People's National Bank \& Trust Co. of Pemberton v. Bichler, 115 N. J. Eq. 617, 172 At1. 207 (Ct. Err. \& App. 1934).

67. See First National Bank of Boston v. Truesdale Hospital, 288 Mass. 35, 192 N. E. 150 (1934).

68. See p. 664 supra.

69. Bowker v. Pierce, 130 Mass. 262 (1881) ; Matter of Clark, 257 N. Y. 132, 177 N. E. 397 (1931).

70. See In re Cook's Trust Estate, 20 Del. Ch. 123, 171 Atl. 730 (Ch. 1934); Matter of Winburn, 140 Misc. 18, 249 N. Y. Supp. 758 '(Surr. Ct. 1931) ; Stirling's Estate, $342 \mathrm{~Pa}$. 497, $21 \mathrm{~A}$. 2d 72 (1941). Where the services advised holding for the "Iong pull," the inference is that they did not think very much of the security as a short term proposition; such evidence is therefore unfavorable to executors faced with a duty to pay off legatees. Matter of Stumpd, 153 Misc. 92, 274 N. Y. Supp. 466 (Surr. Ct. 1934).

71. Kimball v. Whitney, 233 Mass. 321, 123 N. E. 665 (1919) ; Brown v. French, 125 Mass. 410 (1878); Fairleigh v. Fidelity National Bank \& Trust Co., 335 Mo. 360, 73 S. W. 2d 248 (1934); Matter of Clark, 257 N. Y. 132, 177 N. E. 397 (1931); Matter of Andrews, 239 App. Div. 32, 265 N. Y. Supp. 386 (2d Dept. 1933) ; Matter 
similar action. ${ }^{72}$ Following this advice does not by any means absolve him, since that would be an unwarrantable delegation of fiduciary duties. But it does show that he was not alone in his views, and it is difficult to condemn a decision as unsound when it was in accord with the judgment of men of high standing in the financial world.

\section{(b) What was the financial history of the investment?}

This factor is even more obvious than the last one. A fiduciary who has purchased or retained a security is certainly in a stronger position if the corporation's books showed a sound financial structure, ${ }^{73}$ good earnings ${ }^{74}$ and a continuous dividend record ${ }^{75}$ than if they showed spotty earnings, no consistent dividend policy, and a topheavy capitalization or other evidence of financial weakness. Perhaps not coming directly under this topic, but certainly closely related to it, is the management of the company. If the management consists of men who are believed to be extremely able in their field, the investment certainly is more easily defended than if made in securities of a company administered by less capable people. ${ }^{76}$ As to this, however, it should be cautioned that hindsight can far more easily steal in than in

of Horton, 166 Misc. 768, 3 N. Y. S. 2d 215 (Surr. Ct. 1938) ; Matter of Parsons, 143 Misc. 368, 257 N. Y. Supp. 339 (Surr. Ct. 1932), mod., 238 App. Div. 883, 262 N. Y. Supp. 957 (3d Dept. 1933); Casani's Estate, 342 Pa. 468, 21 A. 2d 59 (1941); Gardner's Estate, 323 Pa. 229, 185 Atl. 804 (1936).

72. Green v. Crapo, 181 Mass. 55, 62 i. E. 956 (1902); Matter of Estate of Weston, 91 N. Y. 502 (1883); Matter of Horton, 166 Misc. 768, 3 N. Y. S. 2d 215 (Surr. Ct. 1938).

73. Fairleigh v. Fidelity National Bank \& Trust Co., 335 Mo. 360, 73 S. W. 2d 248 (1934); Matter of Clark, 257 N. Y. 132, 177 N. E. 397 (1931); Lewis' Estate, 344 Pa. 586, 26 A. 2d 445 (1942) ; Clay's Estate, 25 Pa. D. \& C. 257 (O. Ct. 1936); St. Germain's Adm'r. v. Tuttle, 114 Vt. 263, 44 A. 2d 137 (1945). It will be noted that Lewris' Estate and Clay's Estate rely in some measure on the book value of the stock, which is giving weight to one of the least persuasive bits of evidence in the corporate records.

Matter of Winburn, 140 Misc. 18, 249 N. Y. Supp. 758 (Surr. Ct. 1931), has a very practical summary of the most important elements to be considered under this section. The court says:

"What has been the history of the companies during a period of years? Have

they paid regular dividends of regular amounts? Have they a proper capital structure? Are they wisely officered? Has a successful business continued over a period of time? Have they achieved a standing in commercial circles? Have they behind them an established dividend record over a period of years?"

74. Kimball v. Whitney, 233 Mass. 321, 123 N. E. 665 (1919); Clay's Estate, 25 Pa. D. \& C. 257 (O. Ct. 1936); see Matter of Balfe, 152 Misc. 739, 274 N. Y. Supp. 284 (Surr. Ct. 1934), mod., 245 App. Div. 22, 280 N. Y. Supp. 128 (2d Dept. 1935); Curran's Estate, 17 Pa. D. \& C. 423 (O. Ct. 1932), aff'd, 312 Pa. 416, 167 Atl. 597 (1933).

75. Security Trust Co. v. Appleton, $303 \mathrm{Ky} .328,197$ S. W. 2d 70 (1946) ; Green v. Crapo, 181 Mass. 55, 62 N. E. 956 (1902); In re McCann's Will, 212 Minn. 233, 3 N. W. 2d 226 (1942); Lewis' Estate, 344 Pa. 586, 26 A. 2d 445 (1942) ; Seaman's Estate, 333 Pa. 358, 5 A. 2d 208 (1939) ; St. Germain's Adm'r. v. Tuttle, 114 Vt. 263, 44 A. $2 \mathrm{~d} 137$ (1945).

76. Brown v. French, 125 Mass. 410 (1878); Fairleigh v. Fidelity National Bank \& Trust Co., 335 Mo. 360, 73 S. W. 2d 248 (1934); Matter of Balfe, 152 Misc. 739, 274 N. Y. Supp. 284 (Surr. Ct. 1934), mod., 245 App. Div. 22, 280 N. Y. Supp. 128 (2d Dept. 1935). 
the case of the corporate records. Interpretation of the records can be influenced by the passage of time, but the records themselves will remain to aid or plague the fiduciary.

\section{(c) Was the investment (or retention) sound or speculative in nature?}

One of the basic principles of the law of trust administration is that a fiduciary has no right, in the absence of very specific authority, to speculate with his trust funds. The legal list statutes are based entirely on this premise, most of them considering any equity participation as speculative. The prudent man states are much more liberal in defining speculation and rely more on the basic soundness of the corporation and other factors, such as the nature of the transaction, in determining whether there was speculation. The courts in the legal list states use the same approach when they are not bound by the terms of the statute.

The type of security and the background of the corporation will go far toward determining whether the investment is speculative. The tests prescribed under the preceding subhead will provide a large part of the answer. Generally speaking, preferred or common stocks, where not prohibited by statute, in a "well-seasoned" corporation are acceptable for investment and retention. By "well-seasoned" (or similar phrases) the courts seem to mean corporations which have been in existence for a substantial period of time, which are leaders in their field, which have a background of steady earnings and growth, and whose securities, listed on a recognized exchange, are not particularly subject to rapid fluctuations in market price. $^{77}$ On the other hand, stock in a recently-formed corporation, ${ }^{78}$ or an interest in a trading partnership ${ }^{79}$ are frowned upon, as are investments in various other

77. See Security Trust Co. v. Appleton, $303 \mathrm{Ky}, 328,197 \mathrm{~S}$. W. $2 \mathrm{~d} 70$ (1946) ; Green v. Crapo, 181 Mass. 55, 62 N. E. 956 (1902); Brown v. French, 125 Mass. 410 (1878) ; Lovell v. Minot, 20 Pick. 116 (Mass. 1838); Harvard College v. Amory, 9 Pick. 446 (Mass. 1831) ; Matter of Clark, 257 N. Y. 132, 177 N. E. 397 (1931) ; Matter of Kent, 146 Misc. 155, 261 N. Y. Supp. 698 (Surr. Ct. 1932), aff'd, 246 App. Div. 604, 284 N. Y. Supp. 976 (1st Dept. 1935), leave to appeal denied, 270 N. Y. 675 (1936) ; Jenks' Estate, 19 Pa. D. \& C. 479 (O. Ct. 1933) ; Warmack v. Crawford, 195 S. W. $2 d 919$ (Mo. 1946).

Many of the above-cited cases fall short in one respect or another of all the criteria listed in the text; nevertheless, they were all held sound investments by the court. Usually some of the standard of care factors entered in; see note 81 infra.

Testimony by financial experts as to the soundness of securities is admissible. Matter of Winburn, 140 Misc. 18, 249 N. Y. Supp. 758 (Surr. Ct. 1931) ; Chemical Bank \& Trust Co. v. Reynaud, 150 Misc. 821,270 N. Y. Supp. 301 (Sup. Ct. 1933), aff'd, 241 App. Div. 813, 265 N. Y. Supp. 944 (1st Dept. 1933), aff'd, 266 N. Y. 844, 195 N. E. 164 (1934).

78. Mattocks v. Moulton, 84 Me. 545, 24 At1. 1004 (1892) ; Kimball v. Reding, 31 N. H. 352 (1855); see also Appeal of Dickinson, 152 Mass. 184, 25 N. E. 99 (1890).

79. Kinmouth v. Brigham, 5 Allen 270 (Mass. 1862). Although surcharge was not involved, the court considered this question as though it were one of surcharge, 
"unsound" securities. ${ }^{80}$ Despite this rule, the courts have sometimes appeared extraordinarily lenient in allowing retention ${ }^{81}$ of, and in a few cases investment in, some securities that do not appear to meet the tests just outlined. The explanation of this leniency must be found primarily in the fixing of a lower standard of care for the particular fiduciaries involved.

Even if the security itself is sound, it is still possible that the transaction will be deemed speculative. ${ }^{82}$ This depends upon whether its purpose appears to the court to be primarily speculative. No matter how good the faith of the trustee, he is not to try to make a "killing" for his beneficiaries, but to be content with a normal income for the life tenants and security of principal for the remaindermen. The most notorious and frequently-criticized speculation in non-speculative securities is the maintenance of a margin account. ${ }^{83}$ Yet even this conduct is not necessarily speculative, its propriety depending upon the exigencies of the situation under which the fiduciary acted. ${ }^{84}$

and held the trading partnership interest too speculative; in fact, the speculative character of the enterprise loomed so large in the court's mind that it overbalanced the fact that this was a retention of an investment in which decedent had been particularly interested. The decision was sound, but as so often happens, it led to language which does not represent the law. The court, having made up its mind that the retention was improper, said, at page 278 :

". . if the investment is not such as this Court would sustain them in mak-

ing, it should not be allowed to continue, but should be converted."

As we have seen, many cases in Massachusetts have denied the validity of this dictum. Proper analysis by the court would have been: this was an investment of the decedent, and therefore the burden on the beneficiaries to show negligence is fairly heavy, though not so heavy as it would be had there been a discretionary power; by showing that the investment was totally inappropriate for a trust they have met that burden.

80. In re Cook's Trust Estate, 20 Del. Ch. 123, 171 At1. 730 (Ch. 1934) ; Hanscom v. Marston, 82 Me. 288, 19 Atl. 460 (1890); McInnes v. Whitman, 313 Mass. 19, 46 N. E. 2d 527 (1943); Matter of Cady, 211 App. Div. 373, 207 N. Y. Supp. 385 (4th Dept. 1925); Lewis' Estate, 344 Pa. 586, 26 A. 2d 445 (1942).

Somewhat different situations are presented by Creed v. McAleer, 275 Mass. 353, 175 N. E. 761 (1931) and Taylor's Estate, 277 Pa. 518, 121 Atl. 310 (1923). The former was a wasting asset case; in the latter the trustees purchased bonds at a premium, then held them to maturity. In both instances the life tenants were benefited at the expense of the remaindermen, and the court surcharged because the investment was "unsound" from the standpont of protection of corpus. Proper accounting practices should have solved both problems.

81. In In re McCann's Will, 212 Minn. 233, 3 N. W. $2 d 226$ (1942), the court relied in part upon the soundness of the companies involved, but it is unlikely that they would have been considered sufficiently safe to qualify as a "normal" trust investment. Accord, Fairleigh v. Fidelity National Bank \& Trust Co., 335 Mo. 360, 73 S. W. 2d 248 (1934); Dempster's Estate, 308 Pa. 153, 162 Atl. 447 (1932).

82. See Shattuck, The Massachusetts Prudent Man in Trust Investments, $25 \mathrm{~B}$. U. L. REv. 307, 334 (1934).

83. Mathews v. Sheehan, 76 Conn. 654, 57 Atl. 694 (1904); Matter of Hirsch, 116 App. Div. 367, 101 N. Y. Supp. 893 (1st Dept. 1906), aff'd, 188 N. Y. 584, 81 N. E. 1165 (1907); Mellier's Estate, 312 Pa. 157, 167 Atl. 358 (1933).

84. See Reiley v. Healey, 122 Conn. 64, 187 Atl. 661 (1936). Loans continued or taken over in order to retain securities in periods of depression have been upheld in Peck v. Searle, 117 Conn. 573, 169 Atl. 602 (1934) ; Warren v. Pazolt, 203 Mass. 328, 89 N. E. 381 (1909); Gardner's Estate, 323 Pa. 229, 185 Atl. 804 (1936); and Jenks' Estate, 19 Pa. D. \& C. 479 (O. Ct. 1933). 


\section{(d) What was the state of the market?}

This issue never seems to arise as an original investment problem, but always as one of undue retention, where a security (usually in decedent's portfolio, but sometimes purchased earlier by the trustee) was retained hopefully in a steadily falling market, ${ }^{85}$ or a market that dropped suddenly. ${ }^{86}$ The courts have always given weight to this factor, and to the fact of a general depression, in which the market appears not to be reflecting accurately the intrinsic value of the securities being held. ${ }^{87}$

Some investment experts will say, with considerable logic, that a stock that is not sound to buy at a given price should not be retained at that price. Human nature does not seem to work that way, ${ }^{88}$ however, and the sympathy of the courts, equally noticeable in prudent man and legal list states, is quite understandable. Where a stock was being recommended for purchase at 100 , and the next day, without anything apparent having happened to the corporation, it is suddenly selling at 70, it seems harsh to demand that the fiduciary give up hope and at once "bail out" before it goes any lower. Unless something happens to the corporation, he is usually protected; and if something does happen, it usually is reflected in the market price so soon that the trustee still cannot get what he considers a fair price. What this judicial attitude really represents is merely an illustration, in a specific type of case, of a refusal to apply hindsight.

\section{(e) Under the circumstances of the case, was diversification required?}

Although there have always been some investment experts who have denied the soundness of a policy of diversification, it seems to be generally accepted that diversification is a sound investment principle. ${ }^{89}$

85. Bowker v. Pierce, 130 Mass. 262 (1881) ; First National Bank of Boston v. Truesdale Hospital, 288 Mass. 35, 192 N. E. 150 (1934); Kimball v. Whitney, 233 Mass. 321, 123 N. E. 665 (1919) ; Green v. Crapo, 181 Mass. 55, 62 N. E. 956 (1902); Matter of Clark, 257 N. Y. 132, 177 N. E. 397 (1931); Matter of Balfe, 152 Misc. 739, 274 N. Y. Supp. 284 (Surr. Ct. 1934), mod., 245 App. Div. 22, 280 N. Y. Supp. 128 (2d Dept. 1935) ; Allis' Estate, 191 Wisc. 23, 209 N. W. 945 (1926).

86. North Adams National Bank v. Curtiss, 278 Mass. 471, 180 N. E. 217 (1932) Creed v. McAleer, 275 Mass. 353, 175 N. E. 761 (1931); Quinn's Estate, 342 Pa. 509, 21 A. $2 d 78$ (1941) ; Clay's Estate, 25 Pa. D. \& C. 257 (O. Ct. 1936) ; O'Brien's Estate, 18 Pa. D. \& C. 501 (O. Ct. 1933). See also Seaman's Estate, 333 Pa. 358, 364, 5 A. 2d 208, 212 (1939), where the court said, "A fiduciary is not compelled to jettison seasoned investments during a temporary panic."

87. Peck v. Searle, 117 Conn. 573, 169 Atl. 602 (1933); Matter of Estate of Weston, 91 N. Y. 502 (1883) ; Gardner's Estate, 323 Pa. 229, 185 At1. 804 (1936).

88. Most investment advice does not work that way either. Any investment service will contain recommendations to retain stocks that the same service is not placing in a "Buy" category.

89. The theory of diversification is that hard times might come to one company, one industry, or one section of the country, that there might be a drastic slump in equities when secured obligations do not suffer so severely, or that in an inflation the holder of common stocks would be somewhat protected while secured obligations suffered by their comparative immobility. Accordingly, the diversifying investor will 
However, it is a far cry from that to the proposition that a fiduciary who follows a different view should be surcharged for loss. Most of the legal list and some of the prudent man states have refused to take this step, and have held that failure to diversify is no evidence of negligence. ${ }^{90}$ In most prudent man states, however, diversification is at least theoretically required. This theoretical requirement is actually enforced in cases in which the fiduciary is making an investment. ${ }^{91}$ Where, however, he is retaining decedent's investment, the courts have found one way or another to absolve him from liability for loss. ${ }^{92}$ The reason for this practical difference must go back to the standard of care factors. In the retention cases, there is not only the factor of

normally be found with some bonds, some preferred stock, some common stock, and perhaps something else; in addition, the securities will be divided among different industries and among companies operating in different sections of the country.

90. Matter of Adriance, 145 Misc. 345, 260 N. Y. Supp. 173 (Surr. Ct. 1932); Saeger Estates, 340 Pa. 73, 16 A. 2d 19 (1940); Security Trust Co. v. Appleton, 303 Ky. 328, 197 S. W. $2 \mathrm{~d} 70$ (1946); In re McCann's Will, 212 Minn. 233, 3 N. W. 2d 226 (1942).

There is some logic behind a distinction between legal list and prudent man rules on this point. In "legal list" states, the fiduciary is theoretically bound to purchase such high grade investments that risk of loss is at a minimum, and diversification is designed to cut down the risk of loss. A beneficiary could hardly be heard to contend, for example, that a trustee who had invested entirely in $U$. S. bonds was taking an unreasonable risk by not diversifying. This reasoning would not apply so forcefully to real estate mortgages, and should not apply at all where a discretionary power is involved. In that case there is no valid reason for distinction between the two rules, yet the distinction seems to persist even there.

91. Appeal of Dickinson, 152 Mass. 184, 25 N. E. 99 (1890) (but note that partial reliance is placed upon unsoundness of security); Appeal of Davis, 183 Mass. 499, 67 N. E. 604 (1903) ; see Warren v. Pazolt, 203 Mass. 328, 89 N. E. 381 (1909).

In New England Trust Co. v. Paine, 317 Mass. 542, 59 N. E. $2 d 263$ (1945), 320 Mass. 482, 70 N. E. 2d 6 (1946), the court twice grappled with the diversification problem. It pointed out that an original investment in the early part of the century in New England railroad stock was proper in itself; that a disproportionately large investment was probably improper, though in a different category from a purchase of more speculative stock in the same degree. The trustee was finally upheld because of an exculpatory clause. The first opinion infers at p. 555 that a retention of the securities even though in a disproportionate amount might be treated differently.

92. First National Bank of Boston v. Truesdale Hospital, 288 Mass. 35, 192 N. E. 150 (1934) (direction in will-court also mentioned that other stocks had fallen proportionately, but did not mention what bonds had done) ; North Adams National Bank v. Curtiss, 278 Mass. 471, 180 N. E. 217 (1932) (exculpatory clause, interest of decedent) ; Old Colony Trust Co. v. Shaw, 261 Mass. 158, 158 N. E. 530 (1927) (clause in will); Warmack v. Crawford, 195 S. W. 2d 919 (Mo. 1946) (discretionary clause plus interest of decedent).

In Harvard College v. Amory, 9 Pick. 446 (Mass. 1831), 50\% of the trust was in manufacturing stocks, and the problem of diversification was not even mentioned. Though often spoken of as an investment case, because there was a selection by the trustees of securities in the decedent's estate, it still represents a retention of the decedent's investments.

In re Ward's Estate, 121 N. J. Eq. 555, 192 Atl. 68 (Prerog. Ct. 1936), aff'd, 121 N. J. Eq. 606, 191 At1. 772 (Ct. Err. \& App. 1937) is apparently contra. As in Harvard College v. Amory, the trustee was selecting for the trust securities that were in the estate. However, the court actually held that a retention statute did not apply, and that this should be treated as a new investment. In addition, the court was influenced by the lack of care shown by the trustee.

Scott, in Scotr, TRUSTS, $\$ 230.3$ (1939) says that the trustee is under a duty to sell to diversify. The only case he cites for this proposition, however, is Matter of Toel, 180 Misc. 447,39 N. Y. S. 2 d 898 (Surr. Ct. 1943), where there was a specific direction to diversify. 
retention rather than investment, but practically always there is the background of the decedent, ${ }^{93}$ and often there is also a power to retain. A combination of these factors gives the beneficiary an uphill battle, and a trustee who would probably be surcharged for an investment of the same volume in the same securities is allowed to retain without liability. Naturally, a case can be stated where there would be liability for failure to diversify decedent's investment. This would mean only that the beneficiaries had met their heavy burden, and had shown that the trustee was so negligent that he should be surcharged despite the presence of the favorable standard of care factors.

\section{(f) What were the opportunities for selling at a fair price?}

This question involves the problem of blockage, which comes up only rarely. Obviously if a fiduciary wants to sell, and tries to sell, but because of a narrow or nonexistent market cannot sell, he should not be held liable for his failure to do the impossible. This would be practically an absolute defense. ${ }^{94}$

The more normal situation is one wherein the securities could be sold but, because of the narrow market, an apparent sacrifice would have to be made. It is not unusual to see a wide spread between bid and asked prices, or to be able to get bids (for stock in closely-held corporations) only through private sources. Where a trust has a large amount of such stock, the trustee would have to sell at a substantial discount from what the market price for a very small lot would be, and this is taken into account by the courts in determining the wisdom of the trustee's decision. ${ }^{95}$

\section{Affirmative Defenses}

We have now taken up all the important factors which have been considered by the courts in arriving at a decision as to whether, under all the circumstances, a fiduciary was negligent in his administration

93. It is practically impossible to imagine a diversification-retention case in which the background of the decedent does not play an important part. If he was not active in the company he at least had to have placed great confidence in it as an investor or there would not have been a disproportionate amount of it left in his estate. The only case where this would not apply would be one in which the decedent had left a diversified portfolio and the executors had sold all except one or two securities to meet estate obligations.

94. In re Ward's Estate, 121 N. J. Eq. 555, 192 Atl. 68 (Prerog. Ct. 1936), aff'd, 121 N. J. Eq. 606, 191 At1. 772 (Ct. Err. \& App. 1937); Miller's Estate, 345 Pa. 91, 26 A. 2d 320 (1942) ; Reinhard's Estate, 322 Pa. 325, 185 At1. 298 (1936) ; O'Brien's Estate, 18 Pa. D. \& C. 501 (O. Ct. 1933); see Dempster's Estate, 308 Pa. 153, 162 Atl. 447 (1932).

95. Crisman v. Cornel1 University, 132 N. J. Eq. 178, 27 A. 2d 627 (Ch. 1942) ; Glauser Estate, $350 \mathrm{~Pa}$. 192, 38 A. $2 \mathrm{~d} 64$ (1944); Quinn's Estate, $342 \mathrm{~Pa} .509,21 \mathrm{~A}$. 2d 78 (1941) ; Dauler's Estate, 247 Pa. 356, 93 At1. 511 (1915); Matter of Andrews, 239 App. Div. 32, 265 N. Y. Supp. 386 (2d Dept. 1933). See also Rhode Island Hospital Trust Co. v. Copeland, 39 R. I. 193, 98 Atl. 273 (1916). 
of an estate or trust. These factors can eventually be boiled down into one question-did he use that measure of care required of him by the law? This simple statement again brings us back to the analogy of the negligence case, where the answer to the same question will give the answer to at least prima facie liability. However, also as in the negligence case, it is possible for a fiduciary who is apparently liable to surcharge to plead an affirmative defense and, if he can support this plea, escape liability. It should be noted, however, that even an affirmative defense properly proved is not absolute insurance against liability. Bad faith or sometimes reckless indifference to the interests of the beneficiaries would be sufficient to overcome it.

\section{(1) Acquiescence amounting to estoppel}

As pointed out earlier, ${ }^{96}$ acquiescence is sometimes used, or apparently used, to lower the standard of care. In its true form it is supposed to operate as an estoppel and is a complete defense against all acquiescing parties, no defense at all against anybody else. ${ }^{97}$ The classic case would be one in which all the beneficiaries, with full knowledge of all the facts, signified in writing their approval of a course of action (either retention or purchase of the securities) which had been agreed upon between them and the fiduciary. Usually the evidence falls short of this, but it must always contain the two basic elements: knowledge and approval.

Knowledge is best shown by letter or other documentary evidence, ${ }^{98}$ although oral testimony is admissible, ${ }^{99}$ and it has been held that proof of the regular receipt of monthly statements, showing all transactions, as to both income and principal, will suffice. ${ }^{100}$ Agreement of the beneficiaries is usually shown by proof of some kind of positive action. ${ }^{101}$ Some cases have held that silence with knowledge suffices, ${ }^{102}$ but there is a split of authority on this point. ${ }^{103}$

96. See pp. 661-662 supra.

97. See McInnes v. Whitman, 313 Mass. 19, 46 N. E. 2d 527 (1943).

98. Clabby's Estate, $338 \mathrm{~Pa}$. 305, $12 \mathrm{~A}$; 2d 71 (1940); Shipley's Estate (No. 1), 337 Pa. 571, 12 A. 2d 343 (1940) ; Stephens' Estate, 320 Pa. 97, 181 Atl. 559 (1935).

99. Linnard's Estate, $16 \mathrm{~Pa}$. D. \& C. 143 (O. Ct. 1931).

100. Curran's Estate, 17 Pa. D. \& C. 435 (O. Ct. 1932), aff'd, 312 Pa. 416, 167 At1.

597 (1933) ; see Clabby's Estate, 338 Pa. 305, 12 A. 2d 71 (1940).

101. Clabby's Estate, $338 \mathrm{~Pa}$. 305, 12 A. 2d 71 (1940); Stephens' Estate, $320 \mathrm{~Pa}$.

97, 181 Atl. 559 (1935) ; Brown's Estate, 287 Pa. 499, 135 Atl. 112 (1926).

102. Green v. Crapo, 181 Mass. 55, 62 N. E. 956 (1902); Shipley's Estate (No. 1), $337 \mathrm{~Pa} .571,12$ A. 2d 343 (1940) ; Curran's Estate, 17 Pa. D. \& C. 435 (O. Ct. 1932), aff'd, 312 Pa. 416, 167 Atl. 597 (1933); Maser's Estate, 21 Pa. D. \& C. 559 (O. Ct. 1934).

103. In re Cook's Trust Estate, 20 Del. Ch. 123, 171 At1. 730 (Ch. 1934), lays down a very rigid set of rules concerning acquiescence. Under this case, it is necessary that the beneficiary know all the facts, be apprised of his legal rights, be under no disability and act freely, deliberately and advisedly, with the intention of confirming a transaction which he knew or ought to have known was questionable. See also White v. Sherman, 168 Ill. 589, 48 N. E. 128 (1897); In re Shaw, 122 N. J. Eq. 536, 194 Atl. 545 (Prerog. Ct. 1937). 
Although the courts speak of acquiescence operating as an estoppel, all the elements of true estoppel do not necessarily have to be made out. Rarely is reliance by the fiduciary shown, and it does not even seem to be necessary that the acquiescence precede the action later complained of. ${ }^{104}$ To this extent, the estoppel language used by the courts is faulty. Where the acquiescence precedes the action, some kind of reliance might be presumed, but where it follows the action, under such circumstances that a defense of laches cannot be made out, there is really no theory on which a true estoppel can be based, and about all that can be said is that there was ratification. It is probably for this reason that the courts practically always mention other factors along with acquiescence in refusing to surcharge.

\section{(2) Laches}

The defense of laches is the same in a trust surcharge case as it is in any other case. ${ }^{105}$ It is an equitable defense which requires proof that the complaining party, with knowledge of the facts, delayed enforcing his rights for an unconscionable period with resulting detriment to the other party. It thus differs from acquiescence, though both spring from the same basic principle of equity..$^{108}$

\section{(3) An exculpatory clause in the trust instrument}

Superficially, this would seem to be merely an extraordinarily broad discretionary power, and sometimes it seems to be considered in that way. ${ }^{107}$ When it is so treated, it becomes just a particularly strong standard of care factor. Properly analyzed, a discretionary power and exculpatory clause are entirely different in nature. A normal discretionary power says, in effect, "You have discretion to do $X, Y$ or $Z$." The fiduciary thus is allowed greater scope of operation, and will normally be surcharged only for something akin to gross negligence so long as he stays within the boundaries of his power. If he steps beyond these boundaries, the power loses all its force.

An exculpatory clause, on the other hand, gives no discretion, no specific power. It says, in effect, "If you do what you should not do, you are still not to be held liable." This is not an enlargement of

104. See Shipley's Estate (No. 1), 337 Pa. 571, 12 A. $2 d 343$ (1940); Maser's Estate, 21 Pa. D. \& C. 559 (O. Ct. 1934).

105. Phillips v. Rogers, 12 Metc. 405 (Mass. 1847) ; see Pollack v. Bowman, 139 N. J. Eq. 47, 49 A. 2 d 881 (Ct. Err. \& App. 1946) ; Coggins' Appeal, 3 Walker 426 (Pa. 1881); SCOTT, TRUSTS, \$ 219 (1939).

106. This is well brought out by the Maine court in Rodick v. Pineo, 120 Me. 160, 113 Atl. 45 (1921).

107. Warmack v. Crawford, 195 S. W. 2d 919 (Mo. 1946) ; see In re Carr's Estate, 355 Pa. 438, 50 A. 2 d 330 (1947); Appeal of Chaplin, 131 Me. 446, 163 Atl. 774 (1933). 
power, but a limitation of liability. As such it is more in the nature of an affirmative defense than a factor bearing on the standard of care. This clause is most frequently found in wills drawn in prudent man states, because of the prevailing feeling that any lesser clause adds little to the normal discretionary powers of the fiduciary. The clause, where recognized as being more than a discretionary power, is a good defense against negligence, ${ }^{108}$ though public policy prohibits it from operating as a defense against bad faith, and probably against a reckless disregard of the beneficiaries' interests. ${ }^{109}$

\section{CONCLUSION}

An analysis of the cases wherein it is sought to surcharge trustees reveals that the foregoing factors are those which are accorded most weight by the courts. There is discernible in such an analysis a pattern not heretofore apparent in the generalities of opinion and text. An application of this approach to new factual situations could profitably be made by those affected intimately by the surcharge problem. For the practitioner faced with the necessity of marshalling a large and assorted mass of decisions from many jurisdictions, a rationalization can be made out of seeming chaos. To the fiduciary seeking to determine the permissible limits of behavior in the conduct of his duties, the analysis should prove useful in pointing up the details of administration which courts will examine.

108. New England Trust Co. v. Paine, 317 Mass. 542, 59 N. E. $2 d 263$ (1945), 320 Mass. 482, 70 N. E. 2d 6 (1946) ; North Adams National Bank v. Curtiss, 278 Mass. 471, 180 N. E. 217 (1932) ; see Anderson v. Bean, 272 Mass. 432, 172 N. E. 647 (1930). Surprisingly, even in these cases the courts go to great pains to point out other factors which favor the fiduciary. So, although the affirmative defense theory is sound, the courts still like to have as many other factors as possible to rely upon.

109. Restatement, Trusts, $\$ 222$ (1935). See Tavenner v. Baughmann, 41 S. E. 2d 703 (W. Va. 1947), where the clause was not enough to provide immunity where there was an unlawful delegation of duty. 